\title{
THE ROLE OF ATTITUDE IN MEDIATING THE EFFECT OF IMPLEMENTATION OF LOCAL FRUIT PROTECTION LAW ON CONSUMER PURCHASE DECISION IN BALI
}

\author{
Ni Ketut Seminari ${ }^{1}$, I Gusti Agung Ketut Sri Ardani ${ }^{2}$ \\ Program Studi Manajemen \\ Universitas Udayana \\ Bali, Indonesia \\ e-mail: ketutseminari@yahoo.com ${ }^{1}$
}

\begin{abstract}
Abstrak
Buah telah menjadi kebutuhan setiap rumah tangga, bahkan di Bali terutama kebutuhan buah yang sangat tinggi. Kebutuhan ini memberikan peluang bagi buah impor yang merajalela di pasar. Hal ini mengakibatkan buah lokal semakin tersingkir. Padahal buah lokal yang diproduksi di Indonesia sangat beragam. Ini mendorong pemerintah daerah untuk mengeluarkan peraturan No. 3 tahun 2013 tentang perlindungan buah lokal. Adanya peraturan ini ingin mempengaruhi sikap masyarakat sebagai konsumen buah lokal.

Penelitian ini bertujuan untuk menguji pengaruh penerapan Perda terhadap sikap pada keputusan pembelian, pengaruh peraturan lokal terhadap keputusan pembelian, pengaruh sikap terhadap keputusan pembelian, dan peran sikap dalam memediasi implementasi peraturan lokal tentang keputusan pembelian lokal di Bali. Pengumpulan data dilakukan dengan purposive sampling, menggunakan kuesioner. Jumlah responden adalah 105 orang. Data dianalisis menggunakan jalur dan alat analisis uji.

Hasil penelitian menunjukkan bahwa penerapan legislasi perlindungan buah lokal memiliki dampak yang signifikan dan positif terhadap sikap konsumen. Implementasi peraturan buah lokal memiliki dampak yang signifikan dan positif terhadap keputusan pembelian. Sikap memiliki dampak yang signifikan dan positif pada keputusan pembelian konsumen. Serta peran sikap secara signifikan menengahi pelaksanaan undang-undang perlindungan buah lokal pada keputusan pembelian konsumen.

Sebagai saran penelitian, pemerintah dan seluruh masyarakat diharapkan bekerja sama untuk memahami isi peraturan lokal dan membudidayakan buah lokal.
\end{abstract}

Kata Kunci: Sikap, Perda, dan Keputusan Pembelian

\begin{abstract}
Fruit has become the needs of every household, even in Bali especially the need for very high fruits. This need provides an opportunity for rampant imported fruit in the market. This resulted in local fruit getting knocked out. Whereas the local fruit produced in Indonesia is very diverse. This encourages the local government to issue regulation No. 3 of 2013 on the protection of local fruit. The existence of this regulation wants to influence the attitude of the community as a local fruit consumer.

This study aims to examine the effect of Perda implementation on attitudes on purchasing decisions, the effect of local regulations on purchasing decisions, the influence of attitudes on purchasing decisions, and the role of attitudes in mediating the implementation of local regulations on local purchasing decisions in Bali. Data collection was done by purposive sampling, using questionnaire. The number of respondents is 105 people. Data were analyzed using path and test analysis tools.

The results showed that the implementation of local fruit protection legislation has a significant and positive impact on consumer attitudes. Implementation of local fruit regulations has a significant and positive impact on purchasing decisions. Attitudes have a significant and positive impact on consumer purchasing decisions. As well as the role of attitudes significantly
\end{abstract}


mediate the implementation of local fruit protection legislation on consumer purchasing decisions.

As research advice, the government and the whole community are expected to work together to understand the contents of local regulations and cultivate local fruit.

Keywords: Attitude, Perda, and Purchase Decision

\section{PENDAHULUAN}

Alam tropis yang dimiliki Indonesia menjadikan negara ini kaya akan berbagai tanaman. Salah satunya berbagai tanaman buah asli yang dimiliki Indonesia. Beberapa buah tropis sangat baik untuk kesehatan dan bergizi tinggi. Buah merupakan persyaratan dari kelengkapan makanan empat sehat lima sempurna. Buah segar sudah menjadi kebutuhan tiap rumah tangga di Bali. Disamping dikonsumsi tiap hari, kebutuhan untuk mensuplai hotel, juga kebutuhan untuk upacara (membuat banten).

Sehubungan dengan besarnya potensi ekonomi tersebut, diperlukan pengaturan penyelenggaraan peraturan perlindungan buah lokal yang menuntut kejelasan kewajiban dan kewenangan pemerintah daerah, serta hak dan kewajiban pelaku usaha dan masyarakat, yang dijamin oleh kepastian hukum (Peraturan Daerah Provinsi Bali Nomor 3 Tahun 2013 Tentang Perlindungan Buah Lokal).

Beberapa waktu lalu Ketua Umum Asosiasi Eksportir Importir Buah dan Sayuran Segar Indonesia (Aseibssindo) Khafid Sirotudin berharap pemerintah melalui Kementerian Perdagangan perlu mengambil langkah tegas untuk menghentikan impor buah tropis. Pernyataan ini sangat tepat mengingat Indonesia adalah daerah tropis yang sangat banyak menghasilkan berbagai jenis buah.

Pemerintah Provinsi Bali sebenarnya telah memiliki peraturan daerah yang bertujuan mengatur dan melindungi komoditi buah lokal. Peraturan Daerah atau yang sering disingkat dengan Perda merupakan instrumen yang strategis dalam mencapai tujuan desentralisasi. Inisiatif Perda buah lokal muncul kepermukaan sejak 2012 dan disahkan menjadi Perda melalui sidang paripurna pada tahun 2013. Tujuan dan bangunan hukum dari Perda No.3/2013 memang sangat baik dan mendetail guna melindungi buah lokal agar menjadi komoditas utama dalam perdagangan, kepariwisataan serta kemandirian ekonomi masyarakat Bali itu sendiri.

Adanya Perda sudah tentu menimbulkan berbagai sikap di masyarakat Bali dalam keputusan pembelian buah. Dalam hal ini masyarakat ada yang menilai positif, tidak peduli atau negative. Menurut Oliver dan Lee (2010), sikap konsumen adalah hal penting yang akan menjadi pertimbangan dari diri seseorang dalam menilai sebuah produk sampai pada munculnya niat untuk membeli. Mowen dan Minor (1998:249) menyatakan sikap (attitude) yang terbentuk berkaitan dengan hubungan diantara ketiga hal yaitu kepercayaan, sikap dan prilaku. pembentukan sikap konsumen sering kali menggambarkan hubungan antara sikap, kepercayaan dan perilaku. Sikap, kepercayaan dan perilaku juga berkaitan dengan konsep atribut produk. Suprapti (2010:146) mengungkapkan bahwa sikap konsumen terhadap perilaku dapat diukur secara langsung sebagai suatu ukuran yang bersifat menyenangkan terhadap pembeli.

\section{Bauran Pemasaran dan Keputusan Pembelian}

Dalam bauran pemasaran terdapat sekelompok alat pemasaran yang dikenal dalam istilah 4P, yaitu product, place, promotion (promosi), dan price (harga) sedangkan dalam pemasaran jasa mempunyai alat pemasaran tambahan seperti process (proses), people (orang), dan physical evidence (fasilitas fisik) sehingga ada istilah 7P, maka dapat disimpulkan bauran pemasaran jasa yaitu product, place, promotion, price, process, people, dan physical evidence. Menurut Zeithaml dan Bitner (2008:48) : "Bauran pemasaran adalah melakukan komunikasi dengan tamu dan untuk memuaskan tamu" 
Kotler (2008:204) menjelaskan proses pengambilan keputusan pembelian terdiri dari 5 tahapan yaitu, menganalisis keinginan dan kebutuhan, pencarian informasi dan penilaian sumber-sumber pembelian, dan seleksi terhadap alternatif pembelian, keputusan untuk membeli dan perilaku

pembelian.

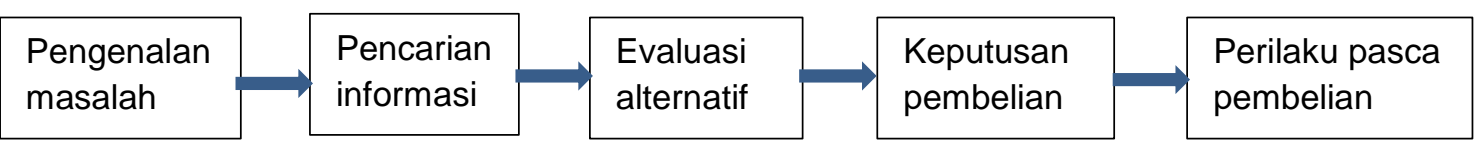

Gambar 1. Model Lima Tahap Proses Pengambilan Keputusan

Sumber: Kotler (2008:179)

\section{Sikap Konsumen}

Sikap adalah suatu kecenderungan yang dipelajari untuk bereaksi terhadap penawaran produk dalam masalahmasalah yang baik ataupun kurang baik secara konsekuen (Dharmmesta dan Handoko, 2012). Setiap unsur dalam definisi ini sangat penting untuk memahami mengapa dan bagaimana sikap terkait dalam perilaku konsumen dan pemasaran. Sikap adalah ungkapan perasaan konsumen tentang suatu objek apakah disukai atau tidak dan sikap juga menggambarkan kepercayaan konsumen terhadap berbagai atribut dan manfaat dari objek tersebut (Sumarwan, 2003:136).

Sikap konsumen bisa merupakan sikap positif ataupun negatif terhadap produk-produk tertentu. Sikap sebagai suatu evaluasi yang menyeluruh dan memungkinkan seseorang untuk merespon dengan cara yang menguntungkan atau tidak terhadap obyek yang dinilai. Menurut Robbins (2006:169) (dalam Wahyuni 2008) sikap adalah pernyataan-pernyataan atau penilaian evaluatif berkaitan dengan obyek, orang atau suatu peristiwa. Sedangkan menurut Simamora (2002:14) (dalam Wahyuni 2008) bahwa di dalam sikap terdapat tiga komponen yaitu : (1) Cognitive component: kepercayaan konsumen dan pengetahuan tentang obyek; (2) Affective component : emosional yang merefleksikan perasaan seseorang terhadap suatu obyek, apakah obyek tersebut diinginkan atau disukai; (3) Behavioral component: merefleksikan kecenderungan dan perilaku aktual terhadap suatu obyek, yang mana komponen ini menunjukkan kecenderungan melakukan suatu tindakan. Menurut Loudan dan Delabitta (2004:217) (dalam Wahyuni 2008); komponen kognitif merupakan kepercayaan terhadap merek, komponen afektif merupakan evaluasi merek dan komponen kognatif menyangkut maksud atau niatan untuk membeli. Dengan mempelajari keadaan jiwa dan keadaan pikir dari sikap seseorang diharapkan dapat menentukan perilaku keputusan pembelian seseorang.

\section{Perda}

Dalam rangka menjalankan

daerah memiliki kemandirian dalam mengatur urusan pemerintahan daerah. Salah satu unsur penting dalam implementasi proses tersebut adalah melalui pembentukan peraturan daerah.

Peraturan Daerah atau yang sering disingkat dengan Perda merupakan instrumen yang strategis dalam mencapai tujuan desentralisasi.

Penelitian ini secara empiris mencoba untuk menyelidiki hubungan antara implementasi Perda perlindungan buah lokal, sikap dan keputusan pembelian. Penelitian bertujuan : (1) Untuk menjelaskan pengaruh implementasi perda perlindungan buah lokal terhadap sikap keputusan pembelian buah lokal; (2) untuk menjelaskan pengaruh implementasi perda perlindungan buah lokal terhadap keputusan pembelian buah lokal; (3) untuk menjelaskan pengaruh sikap terhadap keputusan pembelian buah lokal; (4) untuk menjelaskan peran sikap dalam memediasi implementasi perda 
perlindungan buah lokal terhadap keputusan pembelian buah lokal.

\section{METODE}

Penelitian ini merupakan penelitian asosiatif yang membahas mengenai pengaruh perda terhadap sikap pada keputusan pembelian, perda terhadap keputusan pembelian, sikap terhadap keputusan pembelian, serta peran sikap dalam memediasi perda terhadap keputusan pembelian buah lokal di Bali. Cara mengumpulkan data dan informasi untuk memperoleh fakta-fakta dan keterangan menggunakan kuesioner.

Penelitian ini menggunakan tiga jenis variabel, yaitu: (1) variabel bebas (Independent Variable) yaitu Perda perlindungan buah lokal (X); (2) variabel mediasi (Intervening Variable),sikap konsumen (Y1); (3) variabel terikat (Dependent Variable), dalam penelitian ini yang menjadi variabel terikat adalah keputusan pembelian (Y2).

Berdasarkan hipotesis yang diajukan maka dapat digambarkan desain penelitian sebagai berikut.

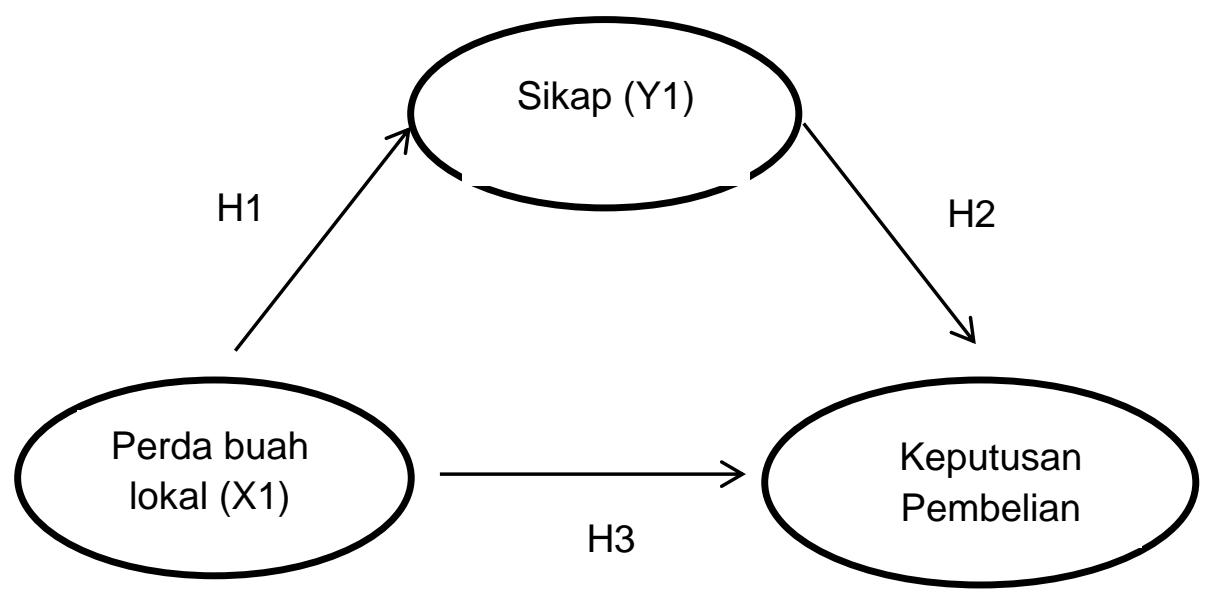

Gambar 2 : Desain Penelitian

\section{Sampel dan Data Penelitian}

Penelitian dilakukan di Kota Denpasar, Kabupaten Badung, Tabanan dan Gianyar. Lokasi ini dipilih karena masyarakat di ke empat daerah ini penggunaan dan peredaran buah impor cukup tinggi. Daerah ini lebih cepat menyerap informasi terkait dengan peraturan-peraturan yang ada. Selain itu lebih mudah untuk memperoleh data dan memahami kuesioner. Obyek penelitian ini adalah peran sikap konsumen dalam memediasi pengaruh perda perlindungan buah lokal terhadap keputusan pembelian. Populasi dalam penelitian ini adalah wanita yang beragama Hindu dan sudah berkeluarga di Kota Denpasar, Kabupaten Badung, Tabanan, dan Gianyar. Penelitian ini menggunakan 15 indikator sehingga sampel yang digunakan sebanyak 105 orang, secara purposif dengan kriteria berikut: (1) perempuan beragama Hindu, sudah menikah, pendidikan terakhir minimal SMP atau sederajat, pernah membeli buah lokal, tahu tentang adanya perda perlindungan buah lokal.

\section{Deskripsi Variabel Penelitian}

Pengumpulan data melalui kuesioner yang terdiri atas pernyataan responden berdasarkan masing-masing variabel, yaitu perda buah lokal, sikap dan keputusan pembelian konsumen. Menurut Suharso (2010: 21) pendeskripsian tanggapan responden mengenai variabelvariabel dalam penelitian dilakukan dengan penggolongan rata-rata skor jawaban responden pada skala pengukuran yang telah ditetapkan lima kategori. 


\section{HASIL DAN PEMBAHASAN}

Tabel 1. Deskripsi jawaban Responden atas Variabel Perda Buah Lokal

\begin{tabular}{|c|c|c|c|c|c|c|c|}
\hline \multirow{2}{*}{ No } & \multirow{2}{*}{ Pernyataan } & \multicolumn{5}{|c|}{ Proporsi jawaban responden (\%) } & \multirow{2}{*}{$\begin{array}{l}\text { Rata- } \\
\text { rata }\end{array}$} \\
\hline & & 1 & 2 & 3 & 4 & 5 & \\
\hline 1 & $\begin{array}{l}\text { Perda Perlindungan Buah Lokal terkesan sebagai } \\
\text { peraturan yang sesuai dengan kondisi lingkungan } \\
\text { keluarga di Bali }\end{array}$ & & 3.8 & 21.0 & 41.0 & 34.3 & 4,05 \\
\hline 2 & $\begin{array}{l}\text { Perda Perlindungan Buah Lokal mempengaruhi } \\
\text { suasana hati lebih baik dalam memanfaatkan buah } \\
\text { lokal untuk dikonsumsi }\end{array}$ & & 3,8 & 18,1 & 38,1 & 40,0 & 4,14 \\
\hline 3 & $\begin{array}{l}\text { Adanya Perda Perlindungan Buah Lokal membuat } \\
\text { saya peduli terhadap pemanfaatan buah lokal }\end{array}$ & & 1,0 & 23,8 & 33,3 & 41,9 & 4,16 \\
\hline 4 & $\begin{array}{l}\text { Adanya Perda Perlindungan Buah Lokal } \\
\text { meyakinkan saya untuk menyukai buah lokal }\end{array}$ & & 2,9 & 20,0 & 43,8 & 33,3 & 4,08 \\
\hline 5 & $\begin{array}{l}\text { Dengan mengkonsumsi buah lokal, saya merasa } \\
\text { telah ikut mengembangkan potensi kekayaan alam } \\
\text { lokal }\end{array}$ & & 1,9 & 16,2 & 39,0 & 42,9 & 4,23 \\
\hline & Rata-rata keseluruhan variabel perda perlindungan $k$ & & & & & & 4,13 \\
\hline
\end{tabular}

Variabel perda buah lokal dalam penelitian ini merupakan variabel bebas yang diukur dengan menggunakan 5 pernyataan. Tabel 1 memperlihatkan bahwa rata-rata tertinggi jawaban responden ditunjukkan pada pernyataan bahwa dengan mengkonsumsi buah lokal, responden merasa telah ikut mengembangkan potensi kekayaan alam lokal, dengan nilai rata-rata 4,23.

Sedangkan nilai rata-rata dari kelima pernyataan yaitu 4,13 masuk dalam kriteria baik. Hal ini berarti bahwa konsumen memiliki persepsi yang baik terhadap perda perlindungan buah lokal.

Pada Tabel 2 tampak nilai rata-rata tertinggi jawaban responden yaitu pada pernyataan saya menyukai adanya perda perlindungan buah lokal. Nilai rata-rata keseluruhan variabel sikap yaitu sebesar 4,06 yaitu kategori baik. Ini berarti bahwa sikap konsumen sangat antusias terhadap diundangkannya perda perlindungan buah lokal.

Tabel 2. Deskripsi jawaban Responden atas Variabel Sikap

\begin{tabular}{|c|c|c|c|c|c|c|c|}
\hline \multirow{2}{*}{ No } & \multirow{2}{*}{ Pernyataan } & \multicolumn{5}{|c|}{ Proporsi jawaban responden (\%) } & \multirow{2}{*}{$\begin{array}{l}\text { Rata- } \\
\text { rata }\end{array}$} \\
\hline & & 1 & 2 & 3 & 4 & 5 & \\
\hline 1 & $\begin{array}{l}\text { Saya menyukai adanya Perda Perlindungan Buah } \\
\text { Lokal }\end{array}$ & & 3.8 & 14.3 & 46.7 & 35.2 & 4.13 \\
\hline 2 & $\begin{array}{l}\text { Saya } \\
\text { mengkonsumsi/menggunakan buah lokal sesuai } \\
\text { dengan Perda Perlindungan Buah Lokal yang } \\
\text { diundangkan }\end{array}$ & & 2.9 & 16.2 & 46.7 & 34.3 & 4.12 \\
\hline 3 & $\begin{array}{l}\text { Saya merasa lebih aman mengkonsumsi buah } \\
\text { local sesuai dengan Perda Perlindungan Buah } \\
\text { Lokal }\end{array}$ & & 6.7 & 25.7 & 31.4 & 36.2 & 3.97 \\
\hline 4 & $\begin{array}{l}\text { Saya lebih suka menggunakan buah lokal untuk } \\
\text { upacara sesuai dengan Perda Perlindungan Buah } \\
\text { Lokal }\end{array}$ & & 1.9 & 22.9 & 39.0 & 36.2 & 4.09 \\
\hline 5 & $\begin{array}{l}\text { Saya yakin gizi buah lokal hampir sama dan } \\
\text { bahkan lebih baik daripada buah impor }\end{array}$ & & 2.9 & 28.6 & 37.1 & 31.4 & 3.97 \\
\hline & Rata-rata keseluruhan variabel sikap & & & & & & 406 \\
\hline
\end{tabular}

Sumber: Data diolah, Keputusan pembelian 
Table 3. Deskripsi jawaban Responden atas Variabel Keputusan pembelian

\begin{tabular}{|c|c|c|c|c|c|c|c|}
\hline \multirow{2}{*}{ No } & \multirow{2}{*}{ Pernyataan } & \multicolumn{5}{|c|}{ Proporsi jawaban responden (\%) } & \multirow{2}{*}{$\begin{array}{l}\text { Rata- } \\
\text { rata }\end{array}$} \\
\hline & & 1 & 2 & 3 & 4 & 5 & \\
\hline 1 & $\begin{array}{l}\text { Saya lebih suka membeli buah lokal daripada } \\
\text { buah impor }\end{array}$ & & 5.7 & 27.6 & 35.2 & 31.4 & 3.92 \\
\hline 2 & $\begin{array}{l}\text { Buah lokal memenuhi harapan saya terhadap } \\
\text { kebutuhan buah untuk dikonsumsi }\end{array}$ & & 9.5 & 26.7 & 39.0 & 24.8 & 3.79 \\
\hline 3 & $\begin{array}{l}\text { Dengan mengkonsumsi buah lokal saya merasa } \\
\text { lebih sehat }\end{array}$ & & 7.6 & 31.4 & 27.6 & 33.3 & 3.86 \\
\hline 4 & $\begin{array}{l}\text { Menggunakan buah lokal dalam banten upacara } \\
\text { mampu meningkatkan citra diri yang baik }\end{array}$ & & 3.8 & 27.6 & 29.5 & 39 & 4.04 \\
\hline 5 & $\begin{array}{l}\text { Saya akan selalu membeli buah lokal untuk } \\
\text { keperluan rumah tangga }\end{array}$ & & 1.9 & 31.4 & 31.4 & 35.2 & 4.00 \\
\hline & Rata-rata keseluruhan variabel keputusan pemb & & & & & & 3.92 \\
\hline
\end{tabular}

Sumber : data diolah 2017

Tabel 3 menunjukkan keseluruhan rata-rata jawaban responden sebesar 3,92 termasuk kategori baik. Artinya konsumen memutuskan untuk melakukan pembelian buah lokal. Rata-rata tertinggi terjadi pada pernyataan yaitu menggunakan buah lokal dalam banten upacara mampu meningkatkan citra diri konsumen, dengan nilai rata-rata sebesar 4,04 . Ini berarti konsumen yang menggunakan buah lokal untuk banten upacara menjadikan citra diri mereka menjadi lebih baik.

\section{Hasil Analisis Faktor Konfirmatori}

1) Kaiser Mayor Olkin (KMO)

Uji Kaiser Mayor Olkin digunakan untuk mengetahui kecukupan sampel. Analisis factor dianggap layak jika besaran $K M O$ memiliki nilai minimal 0,5 . Hasil uji memperlihatkan bahwa semua variabel memiliki $K M O>0,5$. $\mathrm{Hal}$ ini berarti masing-masing variabel memiliki kecukupan sampel untuk analisis factor.
2) Measuring of Sampling Adequancy (MSA)

Kelayakan model uji factor untuk masing-masing variabel dapat dilihat dari Measuring of Sampling Adequancy (MSA). Nilai MSA dari masing-masing variabel lebih besar dari 0,5 . Hal ini berarti masing-masing model layak digunakan dalam analisis factor.

3) Percentage of Variance

Hasil Percentage of Variance menjelaskan kemampuan dari masingmasing factor untuk menjelaskan variasinya. Nilai Percentage of Variance masing-masing variabel sudah lebih besar dari 60 persen.

4) Loading Factor

Nilai Loading Factor yang diperoleh dari masing-masing indicator $\geq 0,05$ yang berarti seluruh indicator dalam penelitian memenuhi syarat untuk menjadi indicator konstruk perda buah lokal, sikap dan keputusan pembelian.

\section{Hasil Analisis Jalur}

Tabel 4. Hasil Analisis Persamaan Regresi 1

\begin{tabular}{|c|c|c|c|}
\hline \multirow[t]{2}{*}{ Model } & \multirow[t]{2}{*}{$R$ Square } & Standardized Coefficients & \multirow[t]{2}{*}{ Sig. } \\
\hline & & Beta & \\
\hline $\begin{array}{l}\text { Perda buah } \\
\text { lokal }\end{array}$ & 0,754 & 0,868 & 0.000 \\
\hline
\end{tabular}

Sumber : data diolah 2017 
Berdasarkan hasil analisis jalur substruktural 1 seperti yang disajikan pada Tabel 4, maka persamaan strukturalnya adalah sebagai berikut:
$Y_{1}=\beta_{1} X+e_{1}$
$Y_{1}=0,868 X+e_{1}$

Tabel 5. Hasil Analisis Persamaan Regresi 2

\begin{tabular}{lccc}
\hline Model & $R$ Square & Standardized Coefficients & \multirow{2}{*}{ Sig. } \\
\cline { 3 - 3 } & & Beta & 0,000 \\
\hline Sikap & 0,833 & 0,361 & 0,000 \\
Keputusan pembelian & & 0,581 &
\end{tabular}

Sumber : data diolah 2017

Berdasarkan hasil analisis jalur substruktural 2 seperti yang disajikan pada Tabel 6, maka persamaan strukturalnya adalah sebagai berikut:

$Y_{2}=\beta_{1} X+\beta_{2} Y_{1}+e_{2}$

$Y_{1}=0,361 X+0,581 Y_{1}+e_{2}$

Menguji nilai koefisien determinasi $\left(R^{2}\right)$ dari variabel error (e)

Berdasarkan model substruktural 1 dan substruktural 2, maka dapat disusun model diagram jalur akhir.sebelum menyusun model diagram jalur akhir, terlebih dahulu dihitung nilai standar error sebagai berikut :

$\mathrm{e}=\sqrt{1-R 1^{2}}$

$\mathrm{e}_{1}=\sqrt{1-R 1^{2}}=\sqrt{1-0,754}=0,496$

$\mathrm{e}_{2}=\sqrt{1-R 2^{2}}=\sqrt{1-0,833}=0,409$

Berdasarkan perhitungan pengaruh error (e), didapatkan hasil pengaruh error $\left(e_{1}\right)$ sebesar 0,496 dan pengaruh $\left(\mathrm{e}_{2}\right)$ sebesar 0,409

Hasil koefisien determinasi total adalah sebagai berikut:

$R^{2} \mathrm{~m}=1-\left(\mathrm{Pe}_{1}\right)^{2}\left(\mathrm{Pe}_{2}\right)^{2}$

$$
=1-(0,496)^{2}(0,409)^{2}=0,921
$$

Nilai determinasi total sebesar 0,921 mempunyai arti bahwa sebesar 92,1 persen variasi keputusan pembelian dipengaruhi oleh Perda buah lokal dan variasi sikap, sedangkan sisanya sebesar 0,079 persen dijelaskan oleh factor lain yang tidak dimasukkan ke dalam model.

Pengaruh variabel secara parsial

Kriteria pengujian untuk menjelaskan interpretasi pengaruh antar masing- masing variabel sebagai berikut: (1) Pengaruh implementasi perda buah lokal terhadap sikap. Berdasarkan hasil analisis pengaruh implementasi perda perlindungan buah lokal terhadap sikap diperoleh nilai signifikan t $0,000<0,05$ dengan nilai statistik t 17,746 mengindikasikan bahwa $\mathrm{H}_{0}$ ditolak dan $\mathrm{H}_{1}$ diterima. Hasil ini berarti implementasi perda buah lokal berpengaruh signifikan dan positif terhadap sikap konsumen terhadap konsumsi buah lokal. (2) Pengaruh implementasi perda buah lokal terhadap keputusan pembelian. Berdasarkan hasil analisis pengaruh implementasi perda buah lokal terhadap keputusan pembelian diperoleh nilai signifikan $t \quad 0,000<0,05$ dengan nilai statistik 4,438 mengindikasikan bahwa $\mathrm{H}_{0}$ ditolak dan $\mathrm{H}_{1}$ diterima. Hal ini berarti Implementasi Perda perlindungan buah lokal berpengaruh positif dan signifikan terhadap keputusan pembelian konsumen. (3) Pengaruh sikap terhadap keputusan pembelian. Sesuai hasil analisis pengaruh sikap terhadap keputusan pembelian diperoleh nilai signifikan t $0,000<0,05$ dengan nilai statistik 7,141 mengindikasikan bahwa $\mathrm{H}_{0}$ ditolak dan $\mathrm{H}_{1}$ diterima. Hasil analisis ini berarti sikap berpengaruh positif dan signifikan terhadap keputusan pembelian konsumen. Meringkas dan menyimpulkan

Hasil koefisien jalur pada hipotesis penelitian dapat digambarkan pada Gambar 3. 


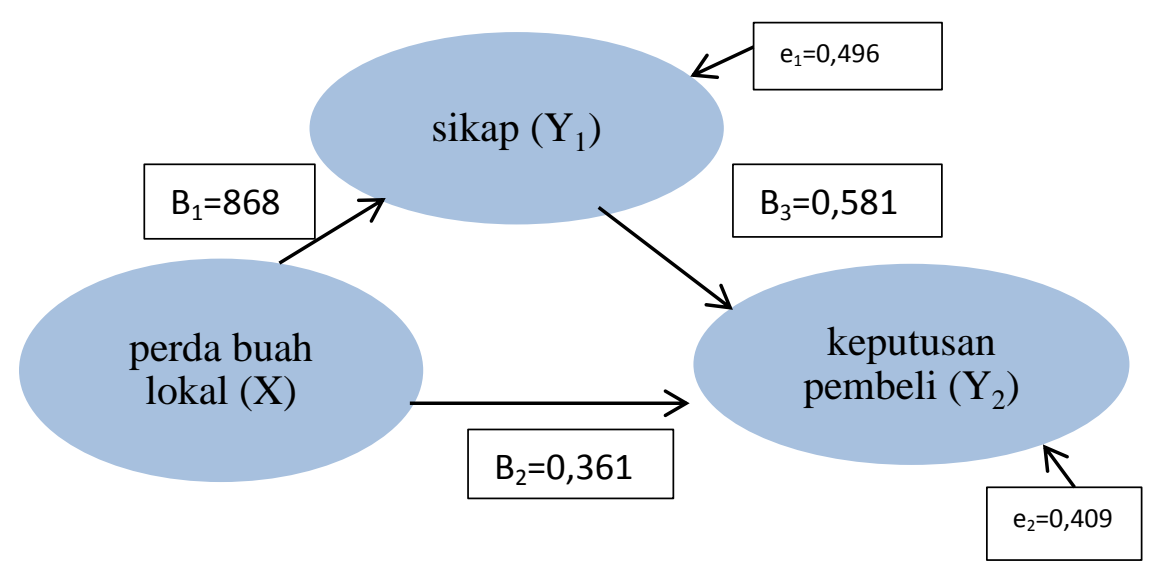

Gambar 3. Validasi model diagram jalur akhir

Tabel 6. Pengaruh langsung, pengaruh tidak langsung dan pengaruh implementasi perda buah lokal $(X)$, Sikap $\left(Y_{1}\right)$, dan keputusan pembeli $\left(Y_{2}\right)$

\begin{tabular}{|c|c|c|c|}
\hline $\begin{array}{l}\text { Pengaruh } \\
\text { Variabel }\end{array}$ & $\begin{array}{l}\text { Pengaruh } \\
\text { Langsung }\end{array}$ & $\begin{array}{l}\text { Pengaruh Tidak Langsung Melalui } \\
\text { sikap }(\mathrm{Y} 1)=\left(\beta_{1} \times \beta_{2}\right)\end{array}$ & Pengaruh Total \\
\hline$X \rightarrow Y_{1}$ & 0,868 & & 0,868 \\
\hline$X \rightarrow Y_{2}$ & 0,361 & 0,313 & 0,674 \\
\hline$Y_{1} \rightarrow Y_{2}$ & 0,581 & - & 0,581 \\
\hline
\end{tabular}

Sumber : data diolah 2017

Uji sobel merupakan alat analisis

untuk menguji hubungan tidak langsung antara variabel independen dengan variabel dependen yang dimediasi oleh variabel mediator.

$\mathrm{S}_{\mathrm{ab}}=\sqrt{\mathrm{a}^{2} \mathrm{~S} b^{2}+\mathrm{b}^{2} \mathrm{~S} a^{2}+\mathrm{S}_{\mathrm{a}}^{2} \mathrm{~S} b^{2}}$

$S a b$ $\sqrt{(0,868)^{2}(0,091)^{2}+(0,581)^{2}(0,05)^{2}+(0,05)^{2},(0}$ $S a b=0,0069$

Untuk menguji signifikansi
pengaruh tidak langsung maka menghitung nilai $z$ dan koefisien $a b$ dengan rumus sebagai berikut :

$$
\begin{aligned}
Z & =\frac{a b}{S a b} \\
& =\frac{(0,868)(0,581)}{0,0069} \\
& =73,08
\end{aligned}
$$

Berdasarkan hasil uji sobel dalam penelitian ini bahwa hasil tabulasi menunjukkan $\mathrm{z}=73,08>1,96$ yang berarti variabel mediasi yakni sikap dinilai secara signifikan memediasi pengaruh implementasi perda perlindungan buah lokal terhadap keputusan pembelian buah lokal oleh konsumen.

\section{Pembahasan}

Hipotesis $\quad \mathrm{H}_{1} \quad$ pengaruh implementasi perda buah lokal terhadap sikap konsumen diterima. Ini menunjukkan bahwa implementasi perda perlindungan buah lokal berpengaruh signifikan dan positif terhadap sikap konsumen pada buab lokal. Hal ini berarti semakin kuat perda perlindungan buah lokal maka sikap konsumen akan semakin baik terhadap pemanfaatan buah lokal.

Hal ini sesuai dengan hasil penelitian Aman et al. (2012) menguji pengaruh kepedulian pada lingkungan terhadap sikap.

Hipotesis kedua yaitu $\mathrm{H}_{2}$ tentang pengaruh implementasi perda buah lokal terhadap keputusan pembelian diterima. Ini menunjukkan bahwa implementasi perda buah lokal berpengaruh signifikan dan positif terhadap keputusan pembelian. Hal tersebut berarti semakin baik implementasi perda perlindungan buah lokal maka keputusan konsumen untuk membeli buah lokal semakin tinggi.

Adanya perda perlindungan buah lokal yang diundangkan pemerintah 
memunculkan sikap konsumen untuk menyukai buah lokal sebagai konsumsi yang diperlukan dalam membuat banten upacara dan dalam konsumsi sehari-hari. Pentingnya perda ini akan berdampak pula bagi pemasar dan petani di Bali khususnya dan Indonesia untuk mengembangkan dan membudidayakan buah lokal.

Hipotesis ketiga $\mathrm{H}_{3}$ tentang pengaruh sikap terhadap keputusan pembelian konsumen diterima. Hal ini memperlihatkan bahwa sikap berpengaruh signifikan dan positif terhadap keputusan pembelian konsumen. Ini berarti semakin baik sikap konsumen maka semakin tinggi keputusan konsumen untuk melakukan pembelian buah lokal.

Hipotesis keempat $\mathrm{H}_{4}$ tentang peran sikap dalam memediasi implementasi perda perlindungan buah lokal terhadap keputusan pembelian konsumen, diterima. Hal ini berarti peran sikap dalam memediasi implementasi perda perlindungan buah lokal berpengaruh signifikan dan positif terhadap keputusan pembelian konsumen. Penelitian ini mendukung hasil penelitian Aman et al. (2012). Sedangkan Paladino (2008) menunjukkan adanya efek mediasi penuh dengan sikap tentang hubungan antara perilaku pembelian hijau dan kepedulian lingkungan.

Peran sikap yang positif terhadap diundangkannya perda perlindungan buah lokal menimbulkan keputusan pembelian buah lokal. Konsumen yang paham terhadap implementasi dari perda memunculkan sikap positif dan memutuskan untuk menggunakan buah lokal dalam kebutuhan buah, baik sebagai sarana dalam banten upacara maupun dikonsumsi langsung untuk kebutuhan sehari-hari.

\section{SIMPULAN}

Berdasarkan hasil penelitian diatas maka dapat disimpulkan beberapa hal sebagai berikut. (1) Implementasi perda perlindungan buah lokal berpengaruh signifikan dan positif terhadap sikap konsumen pada buah lokal; (2) Implementasi perda buah lokal berpengaruh signifikan dan positif terhadap keputusan pembelian; (3) Sikap berpengaruh signifikan dan positif terhadap keputusan pembelian konsumen; (4) Peran sikap dalam memediasi implementasi perda perlindungan buah lokal berpengaruh signifikan dan positif terhadap keputusan pembelian konsumen.

\section{SARAN}

Berdasarkan hasil penelitian diatas maka ada beberapa saran yang dapat di usulkan. (1) Bagi pemerintah diharapkan untuk terus memberikan pemahaman bahwa perda perlindungan buah lokal sesuai dengan kondisi keluarga di Bali; (2) Pemerintah melalui petani harus terus mengembangkan dan membudidayakan buah lokal yang aman dikonsumsi dan buah lokal memiliki gizi yang lebih baik dibanding buah impor; (3) Pemerintah bersama masyarakat harus terus menyerukan untuk mengkonsumsi buah lokal merupakan buah yang sehat.

\section{DAFTAR PUSTAKA}

Alif Effendy (0809291). Pengaruh Sikap Konsumen Terhadap Proses Keputusan Pembelian Notebook ASUS A Series (Survei Kepada Pemilik Notebook ASUS A Series di Grup Facebook ASUS A/K/X/N Series Community Indonesia)

Aman, A.H.L, A. Harun, and Z. Hussein. 2012. The Influence of Environmental Knowledge and Concern on Green Purchase Intention the Role of Attitude as a Mediating Variable. British Journal of Arts and Social Sciences. 7 (2), pp: $145-167$

Bhatnagar, Vidushi and Himani, Grewal. 2012. An Environmental Protection Tool: Green marketing and Its Effect on Consumer Behaviour. International Journal of Emerging Research in Management and Technology. pp: 19-23

Cheah, I. and I. Phau. 2011. Attitudes Towards Environmentally Friendly Products The Influence of Ecoliteracy, Interpersonal Influence 
and Value Orientation. Marketing Intelligence \& Planning. 29 (5), pp: $452-472$

Chen, T.B. dan C.L. Teck. 2010. Attitude towards the Environment and Green Products: Consumers' Perspective. Canadian Research \& Development Center of Sciences and Cultures. 4 (2), pp: 27-39

E-Jurnal Manajemen Unud, Vol. 4, No. 8, 2015 : 2407-2427

Eka Aprilisya. 2017. Peran Sikap Memediasi Pengaruh Pemasaran Hijau Terhadap Niat Beli Produk Ramah Lingkungan. E-Jurnal Manajemen Unud, Vol. 6, No. 4, 2017: 1701-172

http://industri.bisnis.com/read/20170105/1 2/617126/pemerintah-didoronghentikan-impor-buah-tropis

Kadek Ayu Dwi Sudias Kumala Sukma, I Ketut Nurcahya dan Alit Suryani EJurnal Manajemen Unud, Vol. 5, No.7, 2016: 4016-4043

Kotler, Philip. 2012. Principles Of Marketing. Edisi Keempat Belas. United States of America: Pearson Education.

Latan, Hengky. 2012. Structural Equation Modeling: Konsep dan Aplikasi Program Lisrel 8.80. Bandung: Penerbit Alfabeta.

Marhaini. 2008. Analisis Perilaku Konsumen dalam Pembelian Komputer Merek Acer (Studi Kasus: Mahasiswa Fakultas Ekonomi Universitas Sumatera Utara). Jurnal Manajemen Bisnis, 1 (3), h: 89-96.

Oliver, J. D. and Lee, S. H. 2010. Hybrid car purchase intentions: A crosscultural analysis, Journal of Consumer Marketing, 2(2), 96103.
Pradipta, I.B.G.S dan N.W.S. Suprapti. 2013. Pengaruh Sikap dan Norma Subjektif Terhadap Nat Calon Pemilih di Kota Denpasar untuk Memilih Partai Demokrat dalam Pemilu Legislatif 2014. Fakultas Ekonomi Universitas Udayana, Bali - Indonesia

Preacher, K. J and A. F. Hayes. 2004. SPSS and SAS Procedures for Estimating Indirect Effects in Simple Mediation Models. Behavior Research Methods, Instruments, \& Computers. 36(4), pp:717-731

Rahyuda,Ketut. 2016. Metode Penelitian Bisnis, Udayana University Pres.

Schiffman, Leon G. dan Lesli Lazer Kanuk. 2008. Perilaku Konsumen, Diterjemahkan oleh Zoelkifli Kasip. Edisi Ketujuh. Jakarta: PT. Indeks.

Sugiyono.2015. Metode Penelitian Manajemen, cetakan keempat. Alfabeta.

Sumarsono dan Yayat, Giyanto. 2012. Analisis Sikap dan Pengetahuan Konsumen Terhadap Ecolabelling serta Pengaruhnya pada Keputusan Pembelian Produk Ramah Lingkungan. Performance. 15 (1), pp: 70-85

Swastha DH, Basu dan Handoko. (2012). Manajemen Pemasaran, Analisa Perilaku Konsumen. Yogyakarta : BPFE.

Wahyuni, D.U. (2008). Pengaruh Motivasi, Persepsi, dan Sikap Konsumen terhadap Keputusan Pembelian Sepeda Motor Merek Honda di Surabaya Barat. Jurnal Manajemen dan Kewirausahaan. Vol. 10 (1). hal. 30-37.

Wulan Saraswaty dan Sri Suprapti, EJurnal Manajemen Unud, Vol. 4, No. 8, 2015 : 2407-2427. 